\title{
Pengaruh Permainan Papan Perkenalan terhadap Kemampuan Berbicara Anak Usia 5-6 Tahun di TK X Kabupaten Bandung
}

\author{
Shela Isna Noviadana* \\ Prodi Pendidikan Guru PAUD, Fakultas Tarbiyah dan Keguruan, Universitas \\ Islam Bandung, Indonesia. \\ *shelaisnaa@gmail.com
}

\begin{abstract}
The purpose of this study was to determine the effect of introductory board games on the speaking skill for 5-6 years old in Asy Syamsi Kindergarten, Bandung Regency. This study uses a quantitative method with quasi-experimental design and nonequivalent control group design. The sampling method is probability sampling with cluster random sampling technique. The sample of this research is B2-class as an experimental class and B3-class as a control class. Both classes consist of 10 students. Data collection techniques by using observation sheets and documentation. In this study, the instrument prerequisite test is used to test the validity and reliability. The data analysis technique is the normality test using Shapiro Wilk, the homogeneity test using the Levene statistic test, and hypothesis testing using the Paired Sample t-test. The results of hypothesis testing concluded that the value of sig. (2-tailed) $=0.020$, it is smaller than 0.05 . So that it is accepted and H0 is rejected with an average value of 63.90 in the experimental class and an average value of 53.30 in the control class. It can be concluded that there is a significant influence of the introductory board game on the speaking skills for 5-6 years olds in Asy Syamsi Kindergarten, Bandung Regency. The ability to speak with introductory board games in the experimental class increases scores 10,6 than the control class. So it can be said that the introductory board game has an influence on the speaking skills for 5-6 years olds in Asy Syamsi Kindergarten, Bandung Regency.
\end{abstract}

Keywords: Speaking Ability, Board Games, Children 5-6 Years Old

\begin{abstract}
Abstrak. Penelitian ini memiliki tujuan mengetahui pengaruh permainan papan perkenalan terhadap kemampuan berbicara anak usia 5-6 tahun di TK XKabupaten Bandung. Penelitian ini menggunakan pendekatan kuantitatif quasi eksperimental design dengan bentuk nonequivalent control grup design. Teknik pengambilan sampel menggunakan probablility sampling dengan cluster random sampling. Sampel ialah kelas eksperimen (B2) dan kelas kontrol (B3) ssetiap kelas terdiri dari 10 anak didik. Teknik pengumpulan data dengan observasi dan dokumentasi. Teknik analisis data dengan uji normalitas menggunakan Shapiro wilk, uji homogenitas menggunakan uji levene statistik, dan uji hipotesis menggunakan Paired Sample t-test. Hasil pengujian hipotesis disimpulkan bahwa nilai sig. (2-tailed) $=0,020$ lebih kecil dari $\alpha 0,05$, maka Ha di terima dan H0 di tolak dengan mean kelas eksperimen 63,90 dan mean kelas kontrol 53,30 sehingga disimpulkan bahwa terdapat pengaruh signifikan permainan papan perkenalan terhadap kemampuan berbicara anak usia 5 -6 tahun di TK XKabupaten Bandung. Kemampuan berbicara dengan permainan papan perkenalan pada kelas eksperimen meningkatkan nilai yang lebih tinggi 10,6 dibanding kelas kontrol. Sehingga dikatakan bahwa permainan papan perkenalan berpengaruh terhadap kemampuan berbicara anak usia $5-6$ tahun di TK XKabupaten Bandung.
\end{abstract}

Kata Kunci: Kemampuan Berbicara, Permainan Papan, Anak Usia 5-6 Tahun. 


\section{A. Pendahuluan}

Pendidikan Anak Usia Dini dalam Undang - undang No 20 tahun 2003 ialah seluruh aspek perkembangan anak meliputi jasmani maupun rohani yang berupaya untuk dikembangkan dan ditingkatkan sejak anak lahir sampai berusia enam tahun. (Gatot Margono, 2016). Sebagai penyelenggara pendidikan tentu terdapat perkembangan yang harus dicapai, diantaranya perkembangan perilaku yaitu nilai agama dan moral juga perkembangan dasar meliputi bahasa, fisik motorik dan kognitif dan sebagainya. Seluruh indikator perkembangan ini harus distimulasi dengan optimal termasuk salah satunya aspek perkembangan bahasa.

Perkembangan Bahasa (Madyawati, 2016) ialah kemampuan berkomunikasi, berekspresi, memaknai apa yang diucapkan dan dimengerti oleh orang lain. Berkomunikasi bisa dilakukan secara lisan atau tulisan, berbicara ialah sarana lisan yang dapat digunakan saat berkomunikasi atau menjalin hubungan sosial dengan orang lain. Kemampuan berbicara dalam Standar Tingkat Pencapaian Perkembangan Anak (STPPA) termasuk kedalam kemampuan mengungkapkan bahasa (Menteri Pendidikan dan Kebudayaan Republik Indonesia, 2014) yang ditandai pada anak usia 5 - 6 tahun dengan karakteristik "anak dapat menjawab pertanyaan dengan kompleks, menyebutkan kelompok gambar yang memiliki huruf awalan yang sama, berkomunikasi secara lisan, memiliki pembendaharaan kata serta dapat mengenal simbol simbol untuk persiapan membaca, menulis berhitung, menyusun kalimat sederhana dalam struktur lengkap, memiliki banyak kata untuk diekspresikan pada orang lain, melanjutkan sebagian cerita atau dongeng yang telah diperdengarkan dan juga menunjukkan konsep pemahaman dalam buku cerita".

Dari hasil prapenelitian yang dilakukan oleh peneliti di TK Xada 8 anak atau $40 \%$ Belum Berkembang (BB), 7 anak atau 35\% Mulai Berkembang (MB), 3 anak atau 15\% Berkembang Sesuai Harapan (BSH), 2 anak atau 10\% Berkembang sangat Baik (BSB). Kategori tersebut didapat saat peneliti menanyakan nama peserta didik, dengan seksama anak dapat menjawab namanya masing - masing. Namun ketika pertanyaannya diperdalam dengan menanyakan usia, nama orang tua, nama kakak atau adik, dan alamat tempat tinggal. Anak yang menjawab sesuai dengan pertanyaan yang diberikan hanya beberapa anak saja, sisanya cenderung diam dan tidak memperhatikan. Sedangkan karakteristik berbicara pada usia tersebut (Nurbiana Dhieni, 2014) yaitu anak dapat memperkenalkan nama, jenis kelamin dan usia dirinya.

Untuk membantu meningkatkan kemampuan berbicara pada anak, perlu adanya strategi yang dapat membantu guru dalam meningkatkan kemampuan berbicara anak. Salah satunya adalah melalui permainan, dimana hal ini seraya dengan prinsip belajar pendidikan anak usia dini menurut Masnipal (Masnipal, 2018) ialah bermain adalah belajar dan belajar adalah bermain.

Rumusan masalah berdasarkan latar belakang diatas, antara lain:

1. Bagaimana kemampuan berbicara pada anak usia 5-6 tahun di TK XKabupaten Bandung sebelum menggunakan permainan papan perkenalan.

2. Bagaimana kemampuan berbicara pada anak usia 5-6 tahun di TK XKabupaten Bandung sesudah menggunakan permainan papan perkenalan.

3. Apakah terdapat perbedaan permainan papan perkenalan terhadap kemampuan berbicara anak usia 5-6 tahun di TK XKabupaten Bandung.

Adapun penelitian ini bertujuan, yaitu:

1. Untuk mengetahui kemampuan berbicara pada anak usia 5-6 tahun di TK XKabupaten Bandung sebelum menggunakan permainan papan perkenalan.

2. Untuk mengetahui kemampuan berbicara pada anak usia 5-6 tahun di TK XKabupaten Bandung sesudah menggunakan permainan papan perkenalan.

3. Untuk mengetahui pengaruh permainan papan perkenalan terhadap kemampuan berbicara anak usia 5-6 tahun di TK XKabupaten Bandung. 


\section{B. Metodologi}

Penelitian ini mengacu pada pendekatan kuantitatif. Menurut A. Muri Yusuf (Yusuf, A.M., 2017) kuantitatif ialah suatu rancangan penelitian yang terstruktur, formal dan spesifik juga memiliki rancangan operasional yang mendetail. Adapun metode penelitian menggunakan eksperimen yang bertujuan untuk mencari pengaruh suatu treatment tertentu yang dilakukan terhadap suatu kelompok dengan kelompok yang lain sebagai pembanding dalam kondisi yang terkendali (Sugiyono, 2019). Berikut beberapa bentuk desain eksperimen (Sugiyono, 2019)., diantaranya yaitu pre-eksperimental design, true eksperimental design, factorial design dan quasi eksperimental design. Yang digunakan dalam penelitian ini ialah quasi eksperimental design dengan bentuk nonequivalent control group design. Menurut Sugiyono (Sugiyono, 2019) quasi eksperimental design disebut juga dengan eksperimen pura - pura atau eksperimen yang tidak sebenarnya, dalam pelaksanaan eksperimen kelompok kontrol tidak berfungsi seutuhnya untuk mengontrol variabel - variabel diluar yang memiliki pengaruh. Kelompok kontrol dan kelompok eksperimen tidak dipilih melalui randomisasi.

Populasi (Sugiyono, 2019). adalah suatu wilayah umum yang terdiri dari objek-objek atau subjek-subjek dengan sifat dan karakteristik tertentu, yang ditentukan dan disimpulkan oleh peneliti. Subyek penelitian ini adalah seluruh siswa kelas B semester genap TK XKabupaten Bandung Tahun Pelajaran 2020/2021 yang berjumlah 3 kelas, antara lain B1, B2 dan B3 dengan jumlah siswa sebagai berikut:

Siswa/Siswi yang berusia 5-6 tahun di TK XKabupaten Bandung Tahun Ajaran 2020/2021.

Tabel 1. Siswa/Siswi kelas B TK XKabupaten Bandung Tahun Ajaran 2020/2021

\begin{tabular}{|l|l|l|}
\hline No. & Kelas & Jumlah \\
\hline 1. & B1 & 10 \\
\hline 2. & B2 & 10 \\
\hline 3. & B3 & 10 \\
\hline Jumlah & & $\mathbf{3 0}$ \\
\hline
\end{tabular}

Sampel (Sugiyono, 2019). adalah bagian dari jumlah atau karakteristik populasi. Teknik pengambilan sampel menggunakan probability sampling dengan teknik cluster random sampling, dimana siswa dianggap homogen sehingga pengambilan sampel diambil melalui populasi itu sendiri. Sampel penelitian ini adalah kelas eksperimen yaitu Kelas B2 yang terdiri dari 10 anak, berjumlah 5 anak perempuan dan 5 anak laki - laki. Kelas kontrol yaitu kelas B3 terdiri dari 10 anak, berjumlah 5 anak perempuan dan 5 anak laki laki.

Penelitian ini memakai observasi dan dokumentasi sebagai alat pengumpulan data yang akan digunakan. Observasi dengan lembar pengamatan berbentuk ceklis dan dokumentasi untuk membantu peneliti mendapatkan data nama siswa juga foto-foto ketika pelaksanaan penelitian. Teknik analisis data memakai uji normalitas dengan Shapiro Wilk, uji homogenitas dengan uji Levene Statistik dan uji hipotesis dengan Paired Sampel t-test.

\section{Hasil dan Pembahasan}

Penelitian berlokasi di TK XKabupaten Bandung kelas eksperimen (B2) dan kelas kontrol (B3).

\section{Kemampuan Berbicara Pada Anak Usia 5-6 Tahun di TK XKabupaten Bandung Sebelum Menggunakan Permainan Papan Perkenalan}

Agar penelitian ini dapat mengetahui kemampuan berbicara pada anak usia 5-6 tahun di TK XKabupaten Bandung sebelum menggunakan permainan papan perkenalan, peneliti melakukan pretest terlebih dahulu yang dimulai pada kelas eksperimen (B2) dan kelas kontrol (B3) dengan cara melakukan kegiatan pembelajaran menggunakan metode pembelajaran konvensional. Adapun hasil data pretest kemampuan berbicara pada anak usia 5-6 tahun di TK Xsebelum digunakan permainan papan perkenalan, yaitu: 
Tabel 2. Data Pretest Kelas Eksperimen (B2)

\begin{tabular}{|c|c|c|}
\hline Nama & Total Skor & Keterangan \\
\hline 1. & 46 & BB \\
\hline 2. & 43 & BB \\
\hline 3. & 58 & BSH \\
\hline 4. & 41 & BB \\
\hline 5. & 58 & BSH \\
\hline 6. & 53 & MB \\
\hline 7. & 43 & BB \\
\hline 8. & 56 & BSH \\
\hline 9. & 64 & BSB \\
\hline 10. & 51 & MB \\
\hline
\end{tabular}

Berdasarkan tabel diatas, diperoleh temuan penelitian bahwa dari 10 anak menggunakan 20 butir instrumen penelitian, diperoleh hasil pretest penelitian kemampuan berbicara kelas eksperimen dengan skor Belum Berkembang (BB) terdiri dari 4 anak, kategori Mulai Berkembang (MB) terdiri dari 3 anak, kategori Berkembang Sesuai Harapan (BSH) terdiri dari 3 anak, serta indikator Berkembang Sangat Baik (BSB) terdiri dari 1 anak.

Tabel 3. Data Pretest Kelas Kontrol (B3)

\begin{tabular}{|c|c|c|}
\hline Nama & Total Skor & Keterangan \\
\hline 1. & 48 & MB \\
\hline 2. & 47 & BB \\
\hline 3. & 63 & BSH \\
\hline 4. & 43 & BB \\
\hline 5. & 49 & MB \\
\hline 6. & 62 & BSH \\
\hline 7. & 58 & BSH \\
\hline 8. & 44 & BB \\
\hline 9. & 45 & BB \\
\hline 10. & 68 & BSB \\
\hline
\end{tabular}

Berdasarkan tabel diatas, diperoleh temuan penelitian bahwa dari 10 anak serta menggunakan 20 butir instrumen penelitian, diperoleh hasil pretest penelitian kemampuan berbicara kelas kontrol dengan skor Belum Berkembang (BB) terdiri dari 4 anak, kategori Mulai berkembang (MB) terdiri dari 2 anak, kategori Berkembang Sesuai Harapan (BSH) terdiri dari 3 anak, serta kategori Berkembang Sangat Baik (BSB) terdiri dari 1 anak.

Hasil perhitungan data pretest statistik deskriptif data kelas ekseprimen dan kelas kontrol diperoleh dan disajikan berikut ini:

Tabel 4. Statistik Deskriptif Data Pretest

\begin{tabular}{|c|c|c|}
\hline Deskripsi & $\begin{array}{c}\text { Kelompok } \\
\text { eksperimen }\end{array}$ & $\begin{array}{c}\text { Kelompok } \\
\text { Kontrol }\end{array}$ \\
\hline Nilai rata-rata & 51.30 & 52,70 \\
\hline
\end{tabular}

Dalam indikator menjawab pertanyaan yang lebih kompleks peneliti menanyakan nama peserta didik kemudian anak dapat menjawab nama masing - masing dengan seksama. Namun, 
ketika pertanyaannya diperdalam dengan menanyakan usia, nama orang tua, nama kakak atau adik, dan alamat tempat tinggal. Anak yang menjawab sesuai dengan pertanyaan yang diberikan hanya beberapa anak saja, sisanya cenderung diam dan tidak memperhatikan. Sedangkan karakteristik berbicara pada usia tersebut (Nurbiana Dhieni, 2014) yaitu anak dapat memperkenalkan nama, jenis kelamin dan usia dirinya.

Kegiatan ini dilanjutkan dengan anak diminta untuk menyebutkan makanan kesukaannya, hewan kesukaannya, buah kesukaannya, dan warna kesukaannya. Anak dapat menjawabnya dengan jelas dan mudah bagi anak. Namun ketika kegiatan pembelajaran sedang berlangsung, anak tidak luput dari memperebutkan apapun yang dipegang oleh teman lainnya. Hal ini dikarenakan menurut (Rini Hildayani, 2017) anak tertarik dengan apa yang dilakukan teman - temannya atau orang lain dan cenderung untuk meniru. Melalui hal itu anak akan belajar bagaimana berkomunikasi dengan temannya melalui bermain.

Ketika peneliti sedang menceritakan dongeng mengenai si kancil dan buaya anak diminta memperhatikan dan melanjutkan cerita tersebut berdasarkan pandangannya, anak juga diminta menyebutkan judul, pemeran dan pesan moral dalam cerita. Dalam menyebutkannya anak terlihat kesulitan karena kegiatan pembelajaran yang dilakukan selama ini kurang memberi kesempatan pada anak untuk menyebutkan hasil pengamatannya dihadapan teman-temannya. Adapun faktor yang dapat memberi pengaruh (Rini Hildayani, 2017), yaitu faktor emosional dimana anak akan mengungkapkan keinginannya secara verbal jika ia merasa aman dan nyaman dalam mengungkapkan keinginannya. Hal ini akan terus dikembangkan lebih baik lagi jika anak mendapat dukungan dari lingkungan disekitarnya.

\section{Kemampuan Berbicara Pada Anak Usia 5-6 Tahun di TK XKabupaten Bandung Sesudah Menggunakan Permainan Papan Perkenalan}

Setelah dilakukannya pretest, peneliti melakukan kegiatan pembelajaran dengan memberikan treatment pada kelas B2 sebagai kelas eksperimen dengan menggunakan permainan papan perkenalan sedangkan untuk kelas B3 kegiatan pembelajaran dilakukan menggunakan metode pembelajaran konvensional yang pelaksanaannya sama saat melakukan pretest. Hal ini dilakukan agar dapat mengetahui perbedaan kemampuan berbicara pada anak usia 5-6 tahun di TK XKabupaten Bandung sesudah menggunakan permainan papan perkenalan.

Tabel 5. Data Posttest Kelas Eksperimen (B2)

\begin{tabular}{|c|c|c|}
\hline Nama & Total Skor & Keterangan \\
\hline 1. & 77 & BSB \\
\hline 2. & 55 & MB \\
\hline 3. & 77 & BSB \\
\hline 4. & 63 & BSH \\
\hline 5. & 73 & BSB \\
\hline 6. & 47 & BB \\
\hline 7. & 56 & BSH \\
\hline 8. & 62 & BSH \\
\hline 9. & 75 & BSB \\
\hline 10. & 54 & MB \\
\hline
\end{tabular}

Berdasarkan tabel diatas, diperoleh temuan penelitian bahwa dari 10 anak menggunakan 20 butir instrumen penelitian, diperoleh hasil penelitian kemampuan berbicara hasil postest kelas eksperimen dengan skor Belum Berkembang (BB) terdiri dari 1 anak, kategori Mulai berkembang (MB) terdiri dari 2 anak, kategori Berkembang Sesuai Harapan (BSH) terdiri dari 3 anak, serta kategori Berkembang Sangat Baik (BSB) terdiri dari 4 anak

Tabel 6. Data Posttest Kelas Kontrol (B3)

\begin{tabular}{|c|c|c|}
\hline Nama & Total Skor & Keterangan \\
\hline 1. & 59 & BSH \\
\hline
\end{tabular}




\begin{tabular}{|c|c|c|}
\hline 2. & 40 & BB \\
\hline 3. & 46 & BB \\
\hline 4. & 44 & BB \\
\hline 5. & 60 & BSH \\
\hline 6. & 49 & MB \\
\hline 7. & 56 & BSH \\
\hline 8. & 51 & MB \\
\hline 9. & 64 & BSB \\
\hline 10. & 64 & BSB \\
\hline
\end{tabular}

Berdasarkan tabel diatas, diperoleh temuan penelitian bahwa dari 10 anak menggunakan 20 butir instrumen penelitian, diperoleh hasil penelitian kemampuan berbicara nilai postest kelompok kontrol dengan skor Belum Berkembang (BB) terdiri dari 3 anak, kategori Mulai berkembang (MB) terdiiri dari 2 anak, kategori Berkembang Sesuai Harapan (BSH) terdiri dari 3 anak, serta kategori Berkembang Sangat Baik (BSB) terdiri dari 2 anak. Adapun hasil analisis deskriptif data posttest sebagai berikut:

Tabel 7. Statistik Deskriptif Data Posttest

\begin{tabular}{|c|c|c|}
\hline Deskripsi & $\begin{array}{c}\text { Kelompok } \\
\text { eksperimen }\end{array}$ & $\begin{array}{c}\text { Kelompok } \\
\text { Kontrol }\end{array}$ \\
\hline Nilai rata-rata & 63,90 & 53,30 \\
\hline
\end{tabular}

Anak diminta menyebutkan nama benda yang ada di sekitarnya serta menyebutkan huruf konsonan dan vokal berdasarkan indikator berkomunikasi lisan dan memiliki pembendaharaan kata. Anak dapat menyebutkan benda - benda apa yang berada disekitarnya seperti meja, kursi, buku, tas, pensil dll. Ketika anak diminta untuk menyebutkan huruf vokal anak dapat menyebutkannya a, i, u, e, o dengan jelas. Namun ketika anak diminta menyebutkan huruf konsonan, anak tidak menyebutkan semua dengan lengkap tetapi anak sudah mulai paham dengan huruf konsonan. Hal ini sesuai dengan teori Bromley tahun 1992 (Nurbiana Dhieni, 2014) yang menyatakan bahwa anak lebih dulu mengekspresikan fonem vokal seperti a, i, u, e, o dibandingkan dengan fonem konsonan.

Kemampuan berbicara berdasarkan mengekspresikan hasil pemikirannya pada orang lain. Anak dapat mengungkapkan pendapatnya ketika ditanya "Hari ini kita mau main apa?", anak menjawab "aku mau main ini (papan parkenalan)", ketika ditanya kembali tentang perasaannya "Apakah kalian senang hari ini?" kemudian dijawab anak "Senang bu guru". Yang mana menurut (Nurbiana Dhieni, 2014) kemampuan berbicara tidak hanya untuk mengeluarkan suara atau perkataan saja tetapi untuk diekspresikan, disampaikan, dan dikomunikasikan ide juga perasaannya melalui berbicara.

Kemampuan berbicara berdasarkan menunjukan konsep pemahaman dalam buku cerita. Hal ini diukur dengan anak dapat menyebutkan judul cerita dengan jelas, anak dapat menyebutkan pemeran dalam cerita, dan anak dapat menyebutkan pesan moral dalam cerita. Ketika ditanya mengenai judul dan pemeran dalam cerita kancil dan buaya anak dapat menjawab dengan jelas. Namun ketika ditanya mengenai pesan moral anak dibantu oleh peneliti dalam menyebutkan pesan moral dalam cerita kancil dan buaya. Thaiss (Nurbiana Dhieni, 2014) mengungkapkan bahwa anak yang mendapat kesempatan untuk berbicara mengenai suatu informasi akan lebih mengingat dan memahami hal tersebut.

\section{Pengaruh Permainan Papan Perkenalan Terhadap Kemampuan Berbicara Pada Anak Usia 5-6 Tahun di TK XKabupaten Bandung}


Tabel 8. Uji Hipotesis Paired Sampel t-test

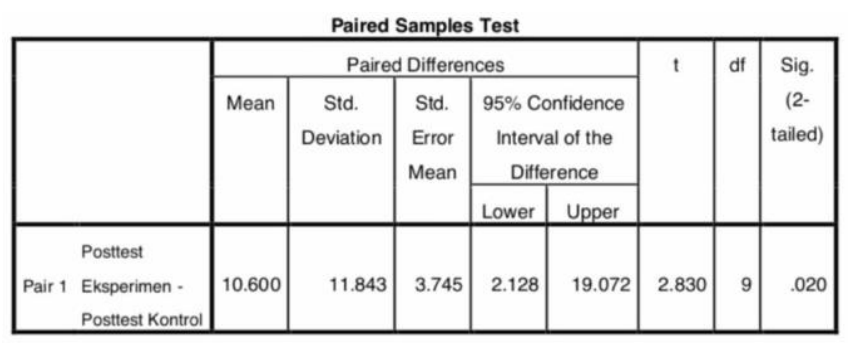

Hasil pengujian hipotesis Paired Sampel t-test, diitemukan kemampuan berbicara dengan menggunakan permainan papan perkenalan lebih baik dibanding dengan kemampuan berbicara menggunakan pembelajaran konvensional yang dilakukan di TK XKabupaten Bandung. Pengujian ini dilakukan untuk mengetahui apakah terdapat perbedaan yang signifikan antara penggunaan permainan papan perkenalan dengan metode pembelajaran konvensional. Anak usia 5-6 tahun di TK XKabupaten Bandung memperoleh kemampuan berbicara yang meningkat setelah diberikan perlakuan menggunakan permainan papan perkenalan.

Hasil analisis data kelas kontrol menggunakan pembelajaran konvensional didapatkan mean pretest sebesar 52,70 dan mean posttest sebesar 53,30 yang berarti terjadi peningkatan skor sebesar 0,6. Hasil analisis data posttest menunjukan mean pada kelas B2 eksperimen kemampuan berbicara menggunakan permainan papan perkenalan pada anak usia 5-6 tahun di TK XKabupaten Bandung sebesar 63,90 dan mean pada kelas B3 kontrol kemampuan berbicara menggunakan pembelajaran konvensional pada anak usia 5-6 tahun di TK Xkabupaten Bandung sebesar 53,30 yang berarti 10,6 lebih besar. Dengan kesimpulan terdapat perbedaan yang signifikan terhadap kemampuan berbicara menggunakan permainan papan perkenalan dengan kemampuan berbicara menggunakan kegiatan pembelajaran konvensional.

\section{Kesimpulan}

Adapun beberapa hasil kesimpulan penelitian ini, sebagai berikut:

1. Sebelum diberi perlakuan kemampuan berbicara anak usia 5-6 tahun di TK XKabupaten Bandung dinilai belum berkembang, hasil pretest menunjukan bahwa anak belum mendapat ketertarikan untuk melakukan kegiatan pembelajaran kemampuan berbicara dengan metode pembelajaran konvensional yang mendapatkan mean pretest sebelum diberikan perlakuan menggunakan permainan papan perkenalan kelas eksperimen sebesar 51,30 dan kelas kontrol sebesar 52,70

2. Kemampuan berbicara anak di TK Xsesudah diberi treatment kepada kelas eksperimen (B2) mengalami peningkatan, berdasarkan perhitungan deskriptif pretest untuk kelompok eksperimen bernilai 51,30 dan posttest bernilai 63,90 dengan simpangan baku pretest bernilai 7,80 dan simpangan baku posttest bernilai 10,94. Sedangkan kelompok kontrol memiliki mean pretest bernilai 52,70 dan posttest bernilai 53,30 dengan simpangan baku pretest bernilai 9,14 dan simpangan baku posttest bernilai 8,52. Dengan demikian hasil kemampuan berbicara anak setelah mendapatkan treatment atau perlakuan permainan papan perkenalan lebih tinggi dibandingkan dengan hasil yang tidak diberi perlakuan dengan menggunakan permainan papan perkenalan.

3. Penggunaan permainan papan perkenalan terhadap kemampuan berbicara pada anak usia 5-6 tahun di TK XKabupaten Bandung memberikan penilaian lebih baik dibanding penggunaan pembelajaran konvensional. Hasil mean kelas eksperimen dan kelas kontrol mengalami peningkatan untuk kelas kontrol bernilai 0,6 dan untuk kelas eksperimen bernilai 10,6 sehingga dapat disimpulkan bahwa terdapat perbedaan yang signifikan antara kemampuan berbicara pada anak usia 5-6 tahun di TK XKabupaten bandung menggunakan permainan papan perkenalan di TK XKabupaten Bandung.

\section{Acknowledge}

Penulis menyampaikan rasa terima kasih kepada :

1. Prof. Dr. H. Edi Setiadi., S.H., M.H, Rektor Universitas Islam Bandung yang sudah 
memberikan fasilitas serta kesempatan kepada penulis untuk meneruskan studi di Universitas Islam Bandung.

2. Enoh Drs. M.Ag, Dekan Fakultas Tarbiyah dan Keguruan Universitas Islam Bandung yang sudah memberi izin dalam menyusun skripsi ini.

3. Dr. Hj. Erhamwilda, Dra. M.Pd, Ketua Jurusan Pendidikan Guru Pendidikan Anak Usia Dini Universitas Islam Bandung yang sudah memberikan dukungan dan motivasi

4. Dr. Asep Dudi Suhardini., S.Ag.,M.Pd sebagai pembimbing I dan Dinar Nur Inten, S.Pd. M.Pd yang dengan kesabarannya membantu mengarahkan serta membimbing penulis dalam penyelesaian studi ini.

\section{Daftar Pustaka}

[1] Chiong, M. C., Artawan, C. A., Wahyudi, A. T., Studi, P., Komunikasi, D., Seni, F., Petra, U. K., \& Siwalankerto, J. (2018). Perancangan Board Game Pembelajaran Bagi Perkembangan Karakter Anak Usia 4-6 Tahun. Jurnal DKV Adiwarna, 1(12), 1-9. http://publication.petra.ac.id/index.php/dkv/article/view/7368/6682

[2] Gatot Margono. (2016). Pengembangan Anak Usia Dini Holistik - Integratif Mewujudkan Anak Yang Sehat, Cerdas, Ceria dan Berakhlak Mulia. Jurnal Pendidikan. http://jurnal.untad.ac.id/jurnal/index.php/Bungamputi/article/view/7314/5894

[3] Hurlock, E. B. (2011). Psikologi Perkembangan: Suatu Pendekatan Sepanjang Rentang Kehidupan. Jakarta: Erlangga. https://bit.ly/3pbd98Y

[4] Inten, D. N. (2017). Pengembangan Keterampilan Berkomunikasi Anak Usia Dini Melalui Metode Bermain Peran. Mediator: Jurnal Komunikasi, 10(1), 109-120. https://doi.org/10.29313/mediator.v10i1.2712

[5] Inten, D. N. (2018). Meningkatkan Penguasaan Kosakata Anak Usia Dini melalui Puisi Lagu Anak. Golden Age: Jurnal Pendidikan Anak Usia Dini, 2(2), 45-52. https://doi.org/10.29313/ga.v2i2.4437

[6] Limantara, D., Heru, D., Waluyanto, D., Pd, M., Zacky, A., \& Sn, M. (2015). Perancangan Board game Untuk Menumbuhkan Nilai-Nilai Moral Pada Remaja. Jurnal Desain Komunikasi Visual Adiwarna, 1(6), 78547.

[7] Madyawati, L. (2016). Strategi Pengembangan Bahasa pada Anak (Edisi pert). Jakarta: Kencana.

[8] Masnipal. (2018). Menjadi Guru PAUD Profesional. PT Remaja Rosdakarya.

[9] Menteri Pendidikan dan Kebudayaan Republik Indonesia. (2014). Standar Nasional Pendidikan Anak Usia Dini. Peraturan Menteri Pendidikan Dan Kebudayaan Republik Indonesia No 137, 13.

[10] Nurbiana Dhieni, dkk. (2014). Metode Pengembangan Bahasa. Tangerang Selatan: Universitas Terbuka.

[11] Rini Hildayani, D. (2017). Psikologi Perkembangan Anak. Universitas Terbuka.

[12] Setiawati, T., Pranata, O. H., \& Halimah, M. (2019). Pengembangan Media Permainan Papan pada Pembelajaran IPS untuk Siswa Kelas V Sekolah Dasar. Pengembangan Media Permainan Papan Pada Pembelajaran IPS Untuk Siswa Kelas V Sekolah Dasar, 6(1), 163174.

[13] Sugiyono. (2019). Metode Penelitian Pendidikan (Kuantitatif, Kualitatif, Kombinasi, R\&D dan Penelitian Pendidikan. Bandung: Alfabeta .

[14] Wulandari, E., \& Sukirno, S. (2012). Penerapan Model Cooperative Learning Tipe Student Teams Achievement Division (Stad) Berbantu Media Monopoli Dalam Peningkatan Aktivitas Belajar Akuntansi Siswa Kelas X Akuntansi 2 Smk Negeri 1 Godean Tahun Ajaran 2011/2012. Jurnal Pendidikan Akuntansi Indonesia, 10(1), 135-161. https://doi.org/10.21831/jpai.v10i1.926

[15] Yusuf, A.M. (2017). METODE PENELITIAN. Kuantitatif, Kualitatif, dan Penelitian Gabungan. . Jakarta: Kencana, Prenada Media Group 